\title{
SLINICAL COMPARISON OF D-TUBOCURARINE AND PANCURONIUM: DOSAGE SCHEDULE BASED ON LEAN BODY MASS
}

\author{
E. NiCKORICK, M.D. AND F.B. REYNOL.DS, M.D.
}

PANCURonium BRomide, a non-depolarizing neuromuscular blocking agent, was first reported in use in anaesthetized patients in 1967 by Baird and Reid. ${ }^{1}$ Pharmacological properties were described by Buckett and associates in 1968. ${ }^{2}$

Pancuronium is a bisquaternary amino steroid said to have approximately five times the potency of d-tubocurarine in man. It is of particular interest to note that this is the first steroid compound with muscle relaxant properties to be used in clinical practice.

\section{PURPOSE OF STUDY}

The study was undertaken to compare the characteristics of Pancuronium to equipotent doses of d-tubocurarine, in a controlled fashion, with regard to onset and duration of action and ease of reversal of the neuromuscular blockade.

\section{METhod}

In order to control as many variables as possible, the patients studied were restricted to females undergoing elective cholecystectomy who were classified as ASA Physical Status I or II. Factors known to affect neuromuscular function were taken into consideration in the pre-operative assessment and any patients found to have such abnormalities were excluded. The pre-medication also was standardized to atropine $0.6 \mathrm{mg}$, intramuscularly, to which was added Innovar ${ }^{\circledR}$ (fentanyl, 0.05 $\mathrm{mg}$; droperidol, $2.5 \mathrm{mg} / \mathrm{ml}$ ) $1 \mathrm{ml}$ per hundred pound body weight administered as close to one hour pre-induction as possible.

Since it is known that the dosage of muscle relaxants does not relate well to body weight or to body surface area, a pilot study was first undertaken to determine whether a better relationship of dose to body characteristics could be found. To this end a modified body surface area was calculated based on lean body mass (LBM) rather than total body mass, according to the following formula:

$$
\begin{aligned}
& \mathrm{LBM}=(100-\% \text { Fat } / 100) \times \text { wt. in Kg, where } \\
& \text { Density }=1.1532-(0.0720)(\log (\text { Total Skinfold Thickness })) \\
& \text { \% Fat }=(4.95 / \text { Density }-4.5) \times 100
\end{aligned}
$$

The usual nomogram for body surface area was used, substituting lean body mass for total body weight. While complete correlation could not be obtained, neverthe-

From The Department of Anaesthesia, University of Saskatchewan and University Hospital, Saskatoon, Saskatchewan.

Presented at the Annual Meeting of Canadian Anaesthetists' Society (Residents' Competition) in Halifax, N.S., June 19--22, 1972.

Canad. Anaesth. Soc. J., vol. 20, no. 2, March 1973 


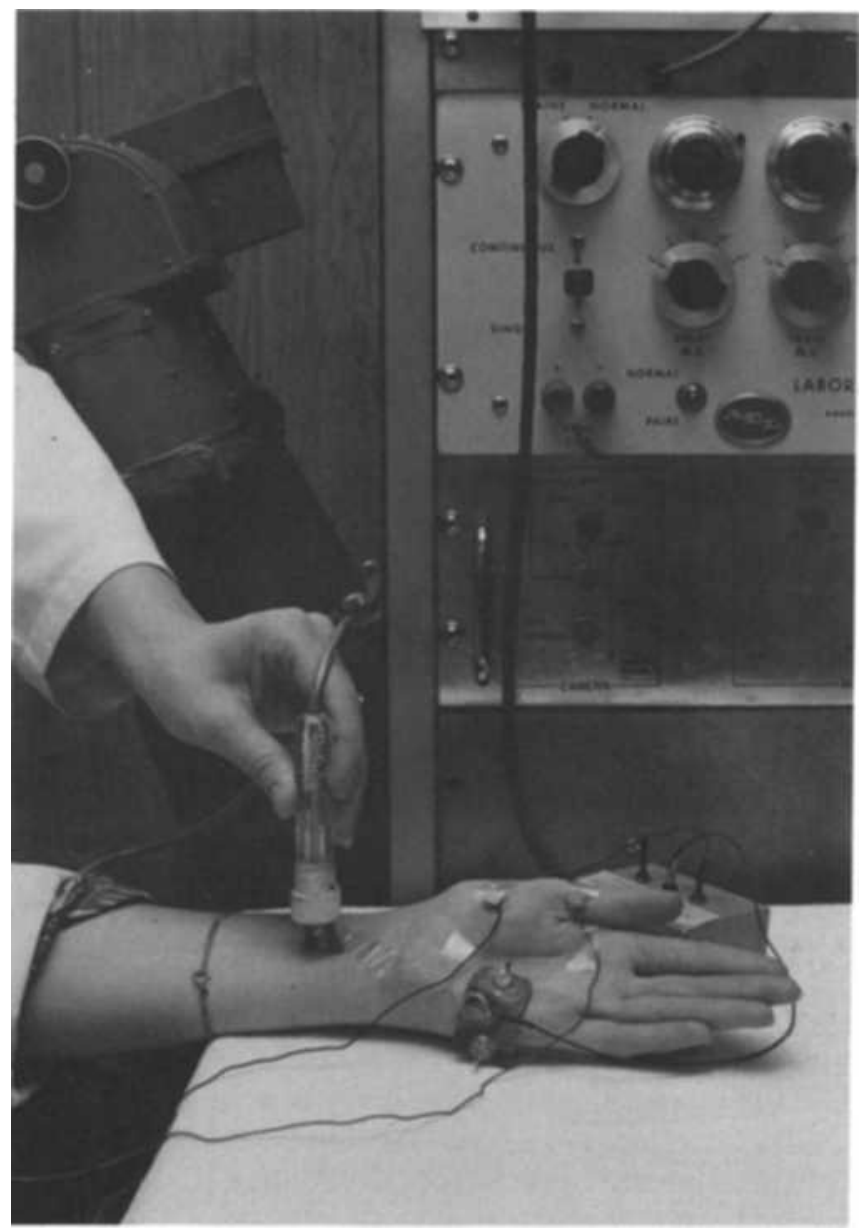

Figure 1. Placement of cutaneous electrodes over the opponens pollicis muscle, with stimulation of the median nerve.

less the correlation of this modified body surface area was a good deal closer than that obtained by using total body weight or body surface area; consequently, this modified body surface area was chosen.

Before induction of anaesthesia determinations were done of serum magnesium, calcium, sodium, potassium and chlorides, serum albumin and total serum proteins, serum cholinesterase, and arterial blood gases. Continuous electrocardiographic and blood pressure monitoring were carried out. Induction doses of muscle relaxants were d-tubocurarine $20 \mathrm{mg} / \mathrm{m}^{2}$ modified body surface area or pancuronium $3 \mathrm{mg} / \mathrm{m}^{2}$ modified body surface area calculated to produce approximately 75 per cent neuromuscular blockade. This was followed by thiopentone $4 \mathrm{mg} / \mathrm{Kg}$ total body weight. The patients' lungs were ventilated for five minutes with nitrous oxide 7 litres and oxygen 3 litres per minute. The trachea was intubated and ventilation continued with an Engstrom ventilator set in such a way as to maintain a $\mathrm{PaCO}_{2}$ at or near control levels. Standard electromyographic recording equipment was used. 

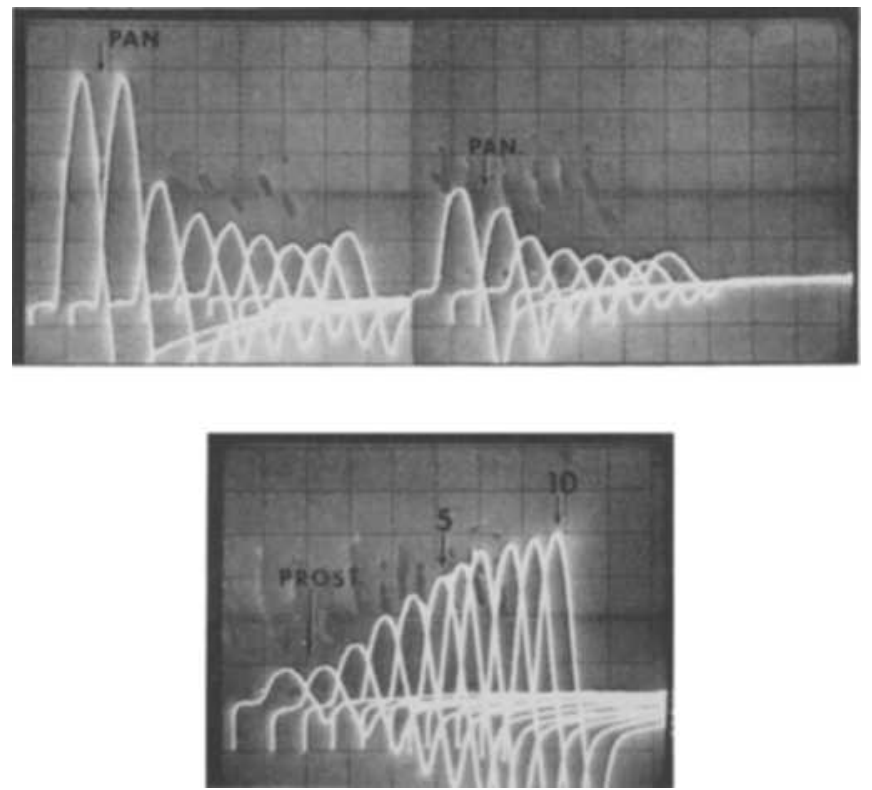

Figure 2. Electromyography of muscle action potentials. (Pan (Pancuronium bromide) Prost (Prostigmine $2.5 \mathrm{mg})(5,10-$ refer to minutes after prostigmine given).)

To determine objectively the degree of muscle relaxation obtained, muscle action potentials were elicited by percutaneous stimulation of the median nerve with pick-up electrodes over the opponens pollicis muscle (Figure 1). Muscle action potentials were recorded and expressed as percentage of the control values taken before induction of anaesthesia.

At the conclusion of the operation, residual effects of the muscle relaxant were reversed with atropine $1.0 \mathrm{mg}$ followed by prostigmine $2.5 \mathrm{mg}$ administered intravenously over a period of 30 seconds. Serial electromyographic tracings were done for five minutes before extubation of the trachea (Figure 2).

\section{Results}

\section{Basic Patient Characteristics}

These are listed in Table I.

(a) Age: This parameter showed the greatest individual variation and also the greatest difference in means between the d-tubocurarine and pancuronium groups. Nevertheless, the degree of neuromuscular blockade seen on the electromyogram was not significantly influenced by age.

(b) Percent Fat: There was a more uniform distribution of fat in the pancuronium as compared to the d-tubocurarine group. Nevertheless, the speed of neuromuscular blockade did not differ significantly between the most obese and the leanest patient in the d-tubocurarine group. This would seem to confirm that lean body mass is indeed preferable to total body weight as a factor in the calculation of the dose of muscle relaxants. 
TABLE I

Patient Age and Habitus

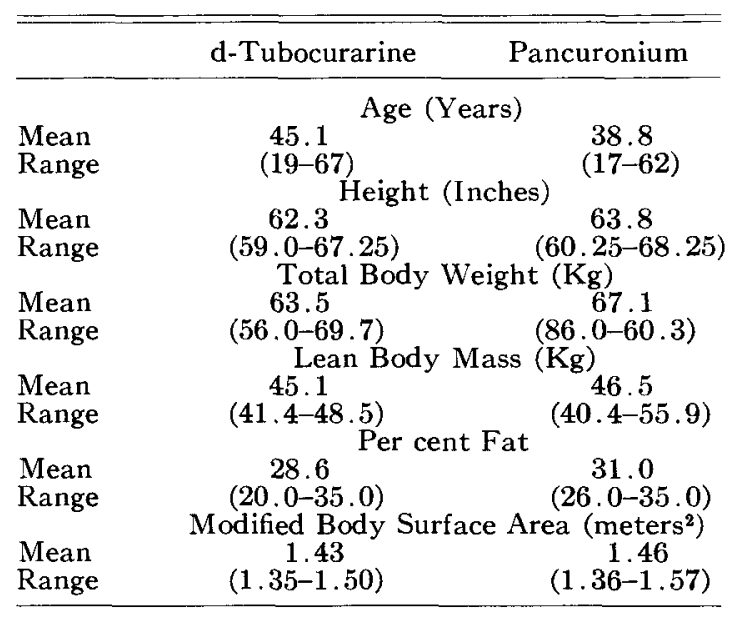

TABLE II

Comparison of Blood Chemistry

\begin{tabular}{lcc}
\hline & d-Tubocurarine & Pancuronium \\
\hline Mean & \multicolumn{1}{c}{ Serum Magnesium (mg $\%)$} \\
Range & 1.6 & 1.6 \\
& $(1.2-1.8)$ & $(1.4-1.8)$ \\
Mean & Serum Calcium (mg $\%)$ \\
Range & 4.6 & 4.6 \\
& $(4.5-5.4)$ & $(4.3-5.0)$ \\
Mean & Serum Albumin $(\mathrm{mg} \%)$ \\
Range & 4.1 & 4.1 \\
& $(4.0-4.4)$ & $(3.5-4.9)$ \\
Mean & Total Serum Proteins $(\mathrm{mg} \%)$ \\
Range & $(6.6-7.7)$ & $(6.8-7.8)$ \\
\hline
\end{tabular}

(c) Others: Significant differences for the two groups were not evident as far as height, total body weight, lean body mass and modified body surface area were concerned.

\section{Comparison of Body Chemistry}

This is shown in Table II. All results were similar for both groups.

\section{Comparison of Acid Base Status}

This is shown in Table III. The $\mathrm{pH}$ of the blood pre-operatively and intra-operatively was similar in the two groups. The $\mathrm{PaCO}_{2}$, however, was lower in the d-tubocurarine group both pre-operatively and during operation and this must be taken into consideration in the light of known potentiation of neuromuscular blockade by acidosis. ${ }^{12}$ 
TABLE III

Comparison of Acid Base Status

\begin{tabular}{lcc}
\hline & d-Tubocurarine & Pancuronium \\
\hline & Blood $\mathrm{pH}$ (Pre-operative) \\
Mean & 7.42 & 7.43 \\
Range & $(7.38-7.50)$ & $(7.38-7.46)$ \\
& Blood $\mathrm{pH}$ (Intra-operative) \\
Mean & 7.45 & 7.44 \\
Range & $(7.39-7.51)$ & $(7.43-7.52)$ \\
& PaCO & $\mathrm{mm} / \mathrm{Hg}$ (Pre-operative) \\
Mean & 31.8 & 36 \\
Range & $(22-38)$ & $(31-43)$ \\
& $\mathrm{PaCO} \mathrm{mm} / \mathrm{Hg}$ (Intra-operatively) \\
Mean & 27.2 & 29 \\
Range & $(24-31)$ & $(24-34)$ \\
\hline
\end{tabular}

TABLE IV

Dosage of Muscle Relaxants

\begin{tabular}{lccc}
\hline & $\mathrm{d}$-Tubocurarine & Pancuronium & Ratio \\
\hline $\begin{array}{l}\text { Initial Dose (mg.) } \\
\begin{array}{l}\text { Mean } \\
\text { Total Dose (mg.) } \\
\text { Mean }\end{array}\end{array}$ & 28.3 & 4.26 & $6.5 / 1$ \\
\hline
\end{tabular}

\section{Dosage of Muscle Relaxants}

The initial mean dose of d-tubocurarine was $28.3 \mathrm{mg}$ and that of pancuronium $4.26 \mathrm{mg}$ for a comparable degree of neuromuscular blockage as determined by the electromyogram. The mean total dose of d-tubocurarine was $37.85 \mathrm{mg}$ and that of pancuronium $5.6 \mathrm{mg}$ (Table IV). Thus, on the basis of both these criteria, pancuronium appears to be approximately 6.5 times as potent milligram for milligram as d-tubocurarine.

\section{Neuromuscular Blocking Activity}

\section{(a) Onset of Action}

There was a more rapid onset of neuromuscular blockade in the pancuronium group as demonstrated by the slope of lines from 2 to 5 minutes and by the presence of greater blockade at the five-minute mark (Figures 3 and 4 ).

The speed of onset of neuromuscular blockade is dose-related as noted in Figure 5.

(b) Time of Maximal Effect

The time of maximal muscle relaxation for the initial dose was in the range of 15 to 20 minutes in both groups. The duration of effect to 50 per cent inhibition was difficult to assess due to need for supplemental doses of muscle relaxants and of Innovar to maintain optimal operating conditions (Figure 6).

The lack of objective uniformity in duration of effect is noted in Figures 3 and 4. The return to 50 per cent inhibition of neuromuscular activity was over a range of 27 to 60 minutes for pancuronium while in two cases of $d$-tubocurarine the neuro- 


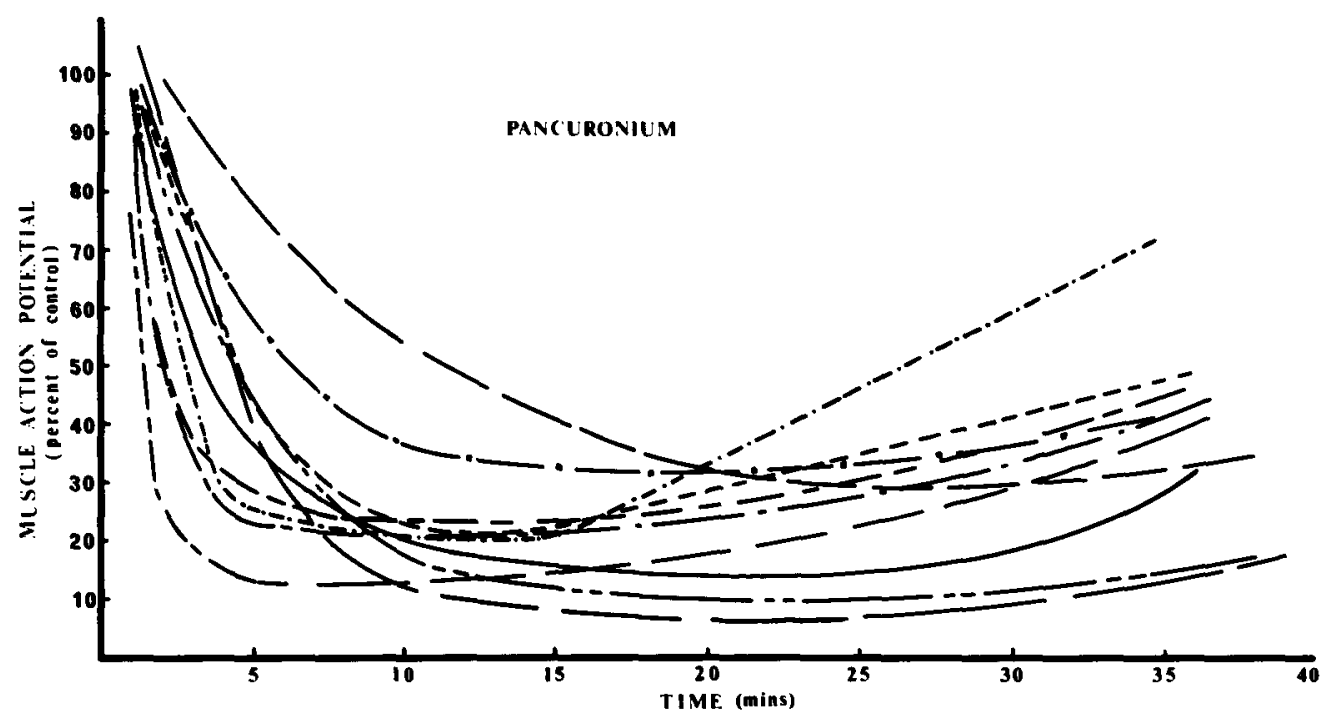

Figure 3. Relationship of neuromuscular blockade with time after pancuronium ( $3 \mathrm{mg} / \mathrm{M}^{2}$ modified body surface area).

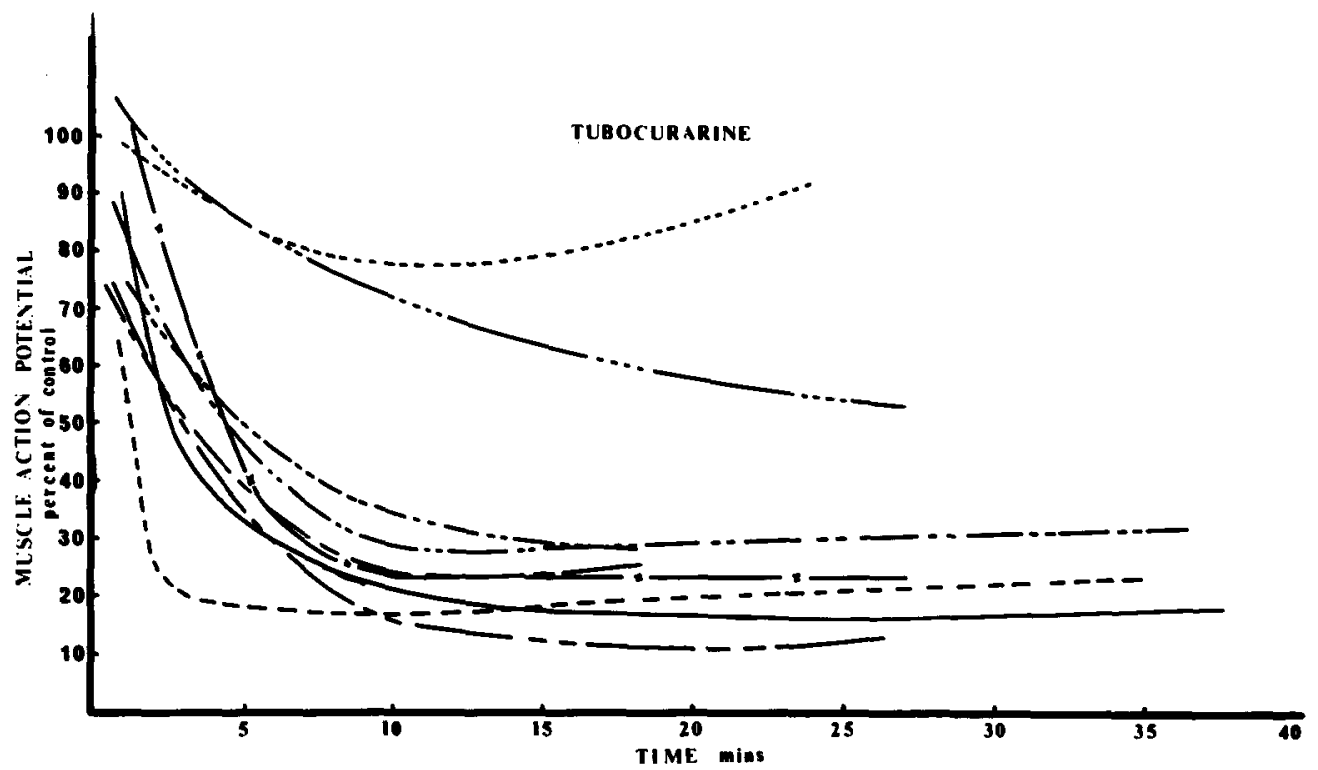

Figure 4. Relationship of degree of neuromuscular inhibition with time for d-tubocurare (20 $\mathrm{mg} / \mathrm{M}^{2}$ modified body surface area ).

muscular conduction had only returned to 15 per cent and 25 per cent of control level at the 55-minute mark.

(c) It is of interest to note that a total of one-half again as much Innovar was used in those patients who received pancuronium as compared to the d-tubocurarine group ( Table V). This is related to the lack of definite objective indicators 


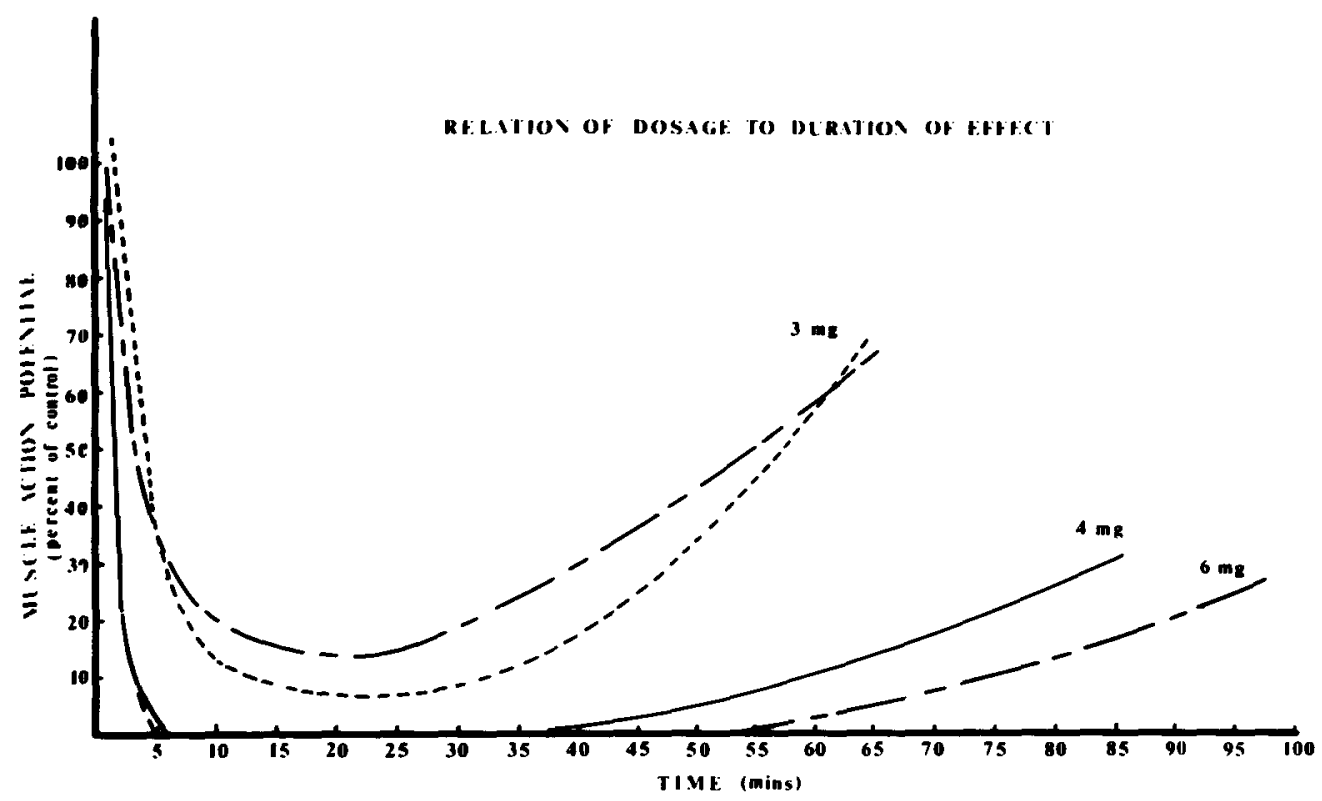

Figure 5. Relation of degree and duration of neuromuscular blockade with increasing doses of pancuronium $\left(3,4\right.$, and $6 \mathrm{mg} / \mathrm{M}^{2} \bmod$. BSA $)$.

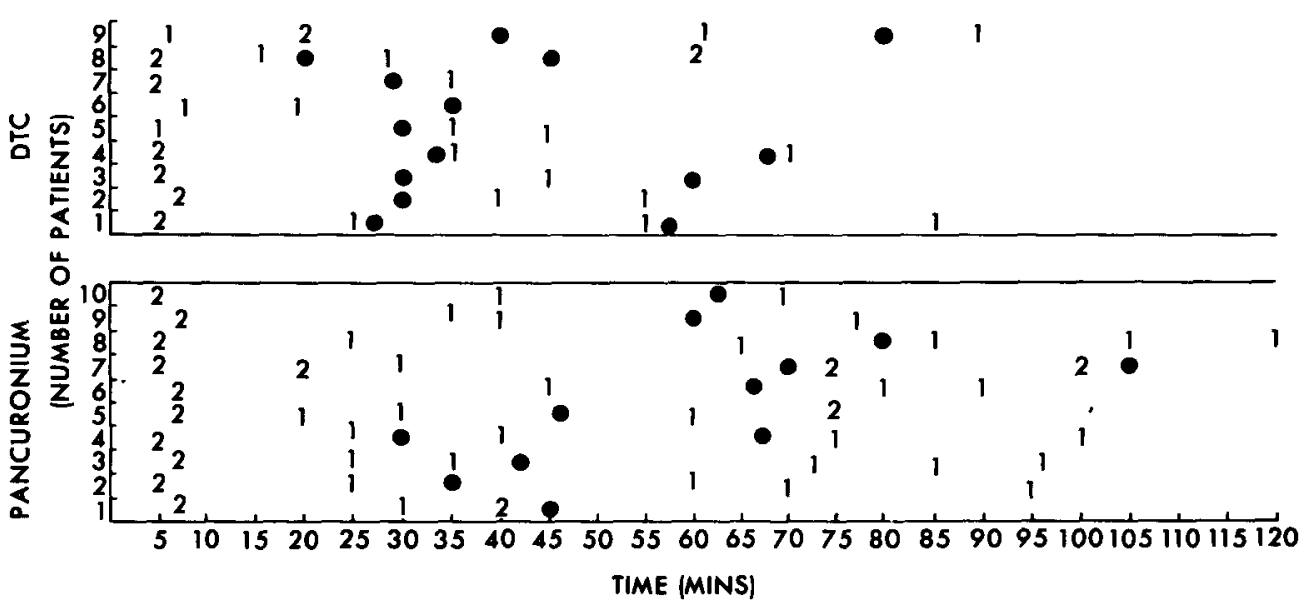

FIGURE 6. Relation of incremental doses of relaxant $(\bullet)$ to incremental doses of Innovar (2cc and lcc aliquots ).

for the incremental doses and the difficulty of maintaining a uniform depth of anaesthesia with this technique. Therefore, conclusions regarding the cardiovascular effect cannot be reached for either of the muscle relaxants under the experimental conditions of this study.

(d) In all instances the residual neuromuscular blockade after either drug was adequately reversed by a single dose of $2.5 \mathrm{mg}$ of prostigmine. The degree of initial reversal was related to the amount of residual block present at that time and 
TABLE V

Dosage of Neurolept Analgesia

\begin{tabular}{lrr} 
& d-Tubocurarine & Pancuroniun \\
\hline $\begin{array}{l}\text { Fentanyl }(0.05 \mathrm{mg} / \mathrm{cc}) \\
\begin{array}{l}\text { Mean } \\
\text { Droperidol }(2.5 \mathrm{mg} / \mathrm{cc})\end{array} \\
\quad 0 \text { Mean }\end{array}$ & $0.21 \mathrm{mg}$. & $0.31 \mathrm{mg}$. \\
\hline
\end{tabular}

TABLE VI

Reversal of Neuromuscular Blockade (Neuromuscular Activity Expressed As Percentage of Control)

\begin{tabular}{ccccccc}
\hline \multicolumn{3}{c}{ d-Tubocurarine } & & \multicolumn{3}{c}{ Pancuronium } \\
\hline $\begin{array}{c}\text { Before } \\
\text { Neostigmine }\end{array}$ & 5 Minutes & 10 Minutes & & $\begin{array}{c}\text { Before } \\
\text { Neostigmine }\end{array}$ & 5 Minutes & 10 Minutes \\
\hline 35.0 & 94.0 & & & 15.0 & 56.0 & 72.0 \\
17.5 & 80.0 & & & 85.0 & 88.0 & \\
36.3 & 59.0 & & & 62.0 & 83.7 & \\
45.5 & 91.0 & & & 52.0 & 109.0 & \\
17.3 & 57.2 & 83.0 & & 89.0 & 109.0 & \\
13.8 & 48.3 & 62.0 & & 43.2 & 102.0 & \\
82.8 & 120.0 & & & 31.4 & 77.0 & \\
10.0 & 40.0 & 57.4 & & 62.0 & 79.3 & \\
62.0 & 86.0 & & & 60.0 & 90.0 & \\
& & & & 42.0 & 92.6 & \\
\hline
\end{tabular}

emphasizes the need to evaluate the degree of neuromuscular transmission before giving the prostigmine (Table VI).

\section{Discussion AND Conclusions}

The use of lean body mass for the calculation of the dose of muscle relaxants results in a close clustering of values of maximal effect around a value of 20 per cent and 25 per cent of control values for d-tubocurarine and pancuronium respectively. There was no significant closer clustering of values for onset than those of Norman, ${ }^{3}$ suggesting use of lean body mass does not improve the dose response predictability. However, the correlation of dosage to effect among the most obese and least obese was good although the numbers are small. Therefore, it would appear that lean body mass is a more logical unit for calculation of muscle relaxant drugs in persons of extreme weight. ${ }^{4-6}$ Some of the variability in effect of the neuromuscular blocking drugs may be related to the cardiac output and peripheral resistance, variables which were not measured in this study. The onset of action of pancuronium has been proven to be faster than that of $\mathrm{d}$-tubocurarine. This coincides with the clinical observation of ease of tracheal intubation noted by PaceFloridia and Pandit ${ }^{7.8}$ and by Catton and Browne. ${ }^{11}$

The difference in duration of clinical effect between the groups appears to be related to the more liberal use of Innovar ${ }^{\circledR}$ in the pancuronium group (Table V). It is of interest that there was no correlation between the objective degree of peripheral neuromuscular blockade and the judgement of the surgeon as to 
the quality of muscle relaxation. The relation of abdominal muscle relaxation to the depression of sensory input was published by $\mathrm{Ngai}^{9}$ and Katz. ${ }^{10}$ It is inherent in the maintenance of some neuromuscular activity peripherally that abdominal musculature will react to intra-peritoneal stimulation. Therefore, the greater use of Innovar in the pancuronium group would overcome the necessity for more relaxant drugs to maintain surgical conditions.

There was wide variation in the course of resolution of the neuromuscular block in both groups which does not correlate with any of the parameters measured. Wulfsohn ${ }^{6}$ was able, however, to relate the duration of neuromuscular blockade to lean body mass.

The residual neuromuscular blockade was reversed with prostigmine objectively and clinically in all patients. Pandit et al. ${ }^{8}$ however demonstrated a rise in $\mathrm{PaCO}_{2}$ in both a d-tubocurarine group and pancuronium group post-operatively in patients who appeared adequately reversed. In their series respiratory acidosis did not give any apparent re-curarization effect.

\section{SUMmary}

(1) Pancuronium bromide is associated with a faster onset of neuromuscular blockade than d-tubocurarine in equipotent doses.

(2) The use of lean body mass allows a more predictable dose-response relationship in people of extreme body weight.

(3) The reversal of residual neuromuscular blockade was adequate and similar in both the pancuronium and d-tubocurarine groups.

\section{RÉSUMÉ}

(1) A doses de force égale, le bromure de pancuronium peut produire un blocage neuro-musculaire dans un délai plus court que ne peut le faire la D-Tubocurarine.

(2) Chez les malades de poids élevé, le poids maigre permettra d'établir une meilleure prévision de la dose-réponse.

(3) Chez les malades des deux groupes: pancuronium et d-tubocurarine, la neutralisation du résidu de blocage neuromusculaire a été serhblable et adéquate.

\section{ACKNOWLEDGMENT}

The authors gratefully acknowledge the assistance received from Messrs. Organon, Inc. who have made available supplies of pancuronium and who have also assisted by providing a grant-in-aid.

\section{REFERENCES}

1. BAIRD, W.L.M. \& REm, A.M. The neuromuscular blocking properties of a new steroid compound pancuronium bromide. Brit. J. Anaesth. 39: 775-780 (1967).

2. BuCKeTT, W.R. \& MAYorebanks, C.E.F. The pharmacology of pancuronium bromide, a new potent steroid neuromuscular blocking agent. Brit. J. Pharmacology 32: 671-682 (1958). 
3. Norman, J., KATZ, R.L., \& SEED, R.F. The neuromuscular blocking action of pancuronium in man during anaesthesia. Brit. J. Anaesth. 42: 702-709 (1970).

4. Wulfsohn, N.L. \& Joshi, C.W. Thiopentone dosage based on lean body mass. Brit. J. Anaesth. 41: 516-521 (1969).

5. Wulfsohn, N.L. Ketamine dosage for induction based on lean body mass. Anesth. and Analg. 51 : 299-305 (1972).

6. Wulfsohn, N.L. D-tubocurarine dosage based on lean body mass. Can. Anaesth. Soc. J. 19: 251-262 (1972).

7. Pace-Flonidia, A. \& Trop, D. The use of pancuronium bromide - a steroidal neuromuscular blocking agent - in prolonged operations. Anesth. and Analg. 50: 987-994 (1971).

8. Pandit, S.K., Dundee, J.W., \& Stevenson, H.M. A clinical comparison of pancuronium with tubocurarine and alcuronium in major cardiovascular surgery. Anesth. and Analg. 50: 926-935 (1971).

9. NgaI, S.H., Hanks, E.C., \& FARKIS, S.E. The effects of anesthetics on neuromuscular transmission and somatic reflexes. Anesthesiology 26: 162-167 (1965).

10. Katz, Ronald L. Comparison of electrical and mechanical recording of spontaneous and evoked muscle activity. Anesthesiology 26: 204-211 (1965).

11. Catron, D.V. \& Browne, R.S. A double blind comparison of pancuronium and d-tubocurarine for endotracheal intubation. Can. Anaesth. Soc. J. 19: 305-308 (1972).

12. Katz, Ronald L. \& Wolf, C.E. Neuromuscular and electromyographic studies in man: effects of hyperventilation carbon dioxide and d-tubocurarine. Anesthesiology 25: 781-787 ( 1964$)$. 